Ann. Zootech., 1980, 29, no h. s., 341-350.

\title{
Investigation on methods of predicting feeding value of feedstuffs for beef cattle in COST-countries
}

\author{
A. STEG \\ Research Institute for Livestock Feeding and Nutrition, \\ Lelystad (The Netherlands)
}

\begin{abstract}
A simple enquiry was made to the methods of predicting feeding value of feedstuffs for beef cattle in COST-countries. Only $0-25$ per cent of the roughage as well as of the concentrates is actually sampled for chemical analysis (mainly Weende procedure). Usually roughages are classified on the face of it and for concentrate ingredients the use of tabulated values is most common. In vitro digestibility procedures, although common for research purposes in nearly all the countries concerned, are not yet frequently used for samples from practice.

Digestibility studies with sheep are the basis for feedstuff evaluation in most countries, but there are differences in feeding level used. A further standardisation is needed to be able to compare digestibility results from different countries. With regard to this some proposals are presented.
\end{abstract}

\section{Résumé}

Recherches sur les méthodes d'estimation de la valeur alimentaire des aliments pour les bovins dans les pays de la Communauté Européenne et des pays associés.

Un questionnaire simple a été établi sur les méthodes d'estimation de la valeur alimentaire des aliments pour les bovins dans les pays de la Communauté Européenne élargie. Seulement 0 à 25 p. 100 des fourrages ainsi que des concentrés utilisés font actuellement l'objet de prélèvement d'échantillons pour analyse chimique (selon la méthode de Weende essentiellement). En général, les fourrages sont évalués à partir de l'analyse et les aliments concentrés le plus souvent à partir de tables de valeurs des constituants. Les méthodes de digestibilité in vitro, bien qu'elles soient habituelles pour les travaux de recherches dans presque tous les pays concernés par l'enquête, ne sont pas actuellement fréquemment utilisées dans la pratique.

Les mesures de digestibilité sur moutons sont à la base de l'évaluation des aliments dans la plupart des pays, mais il existe des différences dans les niveaux d'alimentation utilisés pour ces mesures. Une meilleure standardisation est nécessaire pour pouvoir comparer les résultats de digestibilité entre différents pays. Sur ce point, différentes propositions sont faites dans ce texte. 


\section{1. - Introduction}

As there is lack of information how prediction of feeding value of feedstuffs is done in COST-countries, the Nutrition-Management Scientific Group of COST decided at the 9 March 1978 meeting in Brussels that a simple enquiry should be made. In co-operation with Dr VAN Es a questionnaire was set up (see appendix) and sent by the CEC-secretariat to the representatives of Belgium, Denmark, Finland, France, West Germany, Greece, Ireland, Italy, Luxemburg, the Netherlands, Portugal, Sweden, Switzerland, Turkey, United Kingdom and Yugoslavia. All returned the completed form in 1978 except Portugal and Turkey.

The results of the questionnaire will be summarised here, roughly following the questions that were put and some comments will be made.

\section{2. - Energy and protein evaluation systems used}

\section{Energy}

In the 14 countries concerned at least 7 different energy evaluation systems for beef cattle are used. Some countries even use two systems simultaneously. A picture of the systems used in the countries concerned is given in Figure 1.

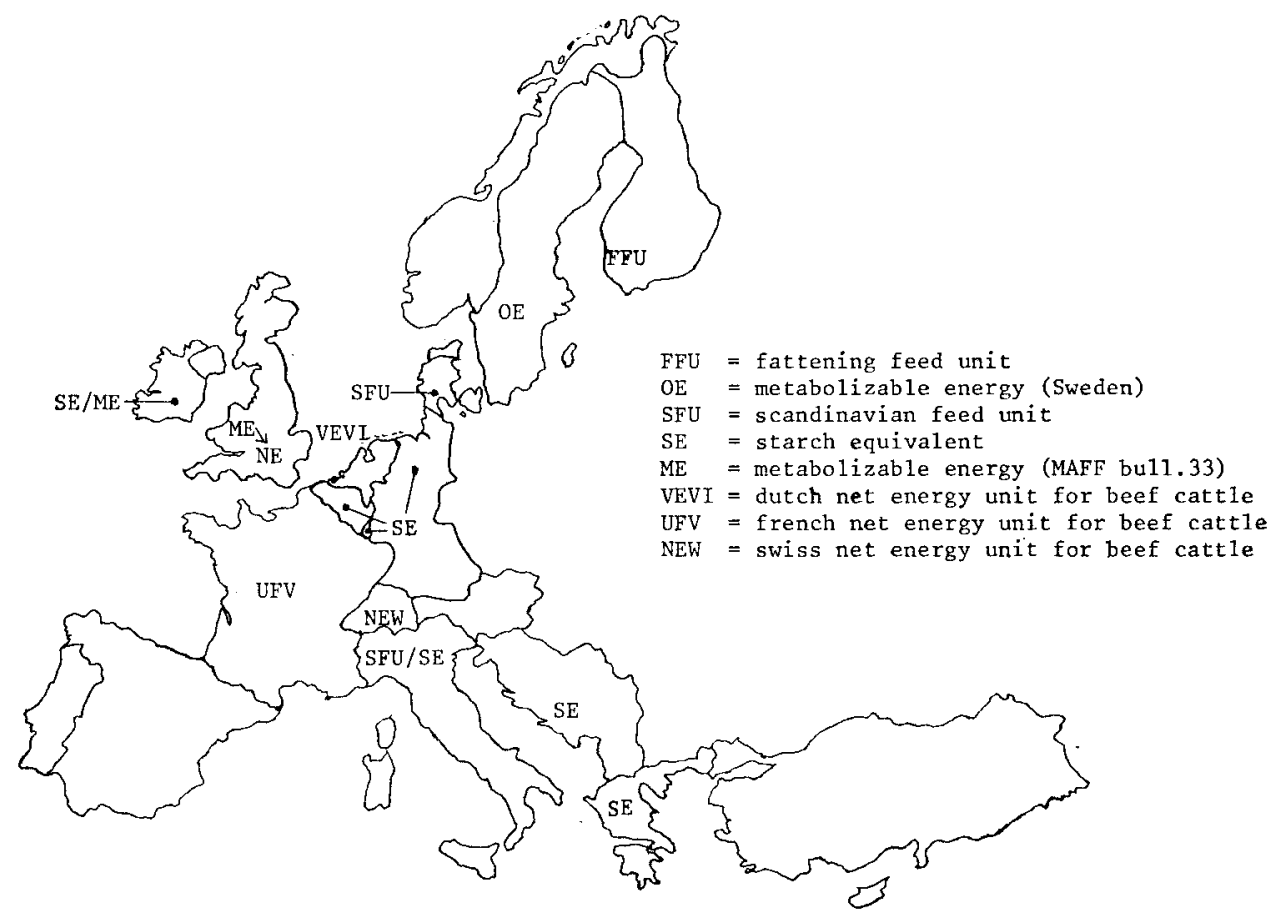

FIG. 1. - Energy systems used. 
Characteristics of the calculation of energy values are discussed in Session 1 of this seminar. It should be remarked that all systems essentially start from digestible components of the feedstuffs as determined with wethers, and for the FFU, OE, SE and SFU-systems there is no essential difference in the way of calculation of feeding value for beef cattle and for dairy cattle. For several of these systems basic items for the calculation of energy value of feedstuffs are presented in a publication on feed evaluation for dairy cows by STEG and VAN DER HONING (1979!.

\section{Protein}

Most countries employ (1978) digestible crude protein or a slight modification of it, feeding standard crude protein, as the unit for protein value of feedstuffs.

In France also PDI-value $=$ true protein truly digestible in the small intestine has been used since 1978 (Alimentation des Ruminants, INRA). For Luxemburg and Italy crude protein is mentioned as an additional unit.

\section{3. - Prediction of feeding value in practice}

\section{Roughages}

We tried to investigate to what extent at the farm level feeding tables and chemical analysis of feed samples are used to predict the feeding value of feedstuffs.

For the Netherlands it was estimated that 20 per cent of the roughage is sampled for chemical analysis and that for 40 per cent feeding values are predicted with the help of the feeding table.

Unfortunately, the question obviously led to some misunderstanding. The completed forms of some countries did not mention any percentage, while the forms of Italy and Luxemburg mentioned a very high percentage for chemical analysis of roughage. Table 1 gives a survey of the results. United Kingdom and Ireland also use the Tilley and Terry in vitro procedure. For Ireland an extremely high figure of 80 per cent is mentioned of the roughage being analysed in practice this way. When roughages samples are chemically analysed, the following analyses are done in each country : dry matter, crude ash (or total ash), crude protein, crude fibre. Crude fat is also mentioned for 7 countries, presumably dependent upon the type of product. In the United Kingdom and Ireland some products are analysed for modified acid detergent (MADF) instead of crude fibre.

For silages in Belgium and the Netherlands the $\mathrm{NH}_{3}$-fraction $\left(\mathrm{NH}_{3}-\mathrm{N}\right.$ as a percentage of total $\mathrm{N}$ ) is additionally measured. Pepsin-HCl-digestibility of crude protein, as the Swiss form mentioned, is measured incidentally in several countries.

When chemical composition of a roughage sample is known, two pathways to predict feeding value can be followed :

a. A feeding table is consulted to find those digestibility coefficients which correspond with the composition ;

b. (Multiple) regression equations are used to predict digestible components (or energy values directly) from chemical characteristics. 
A. STEG

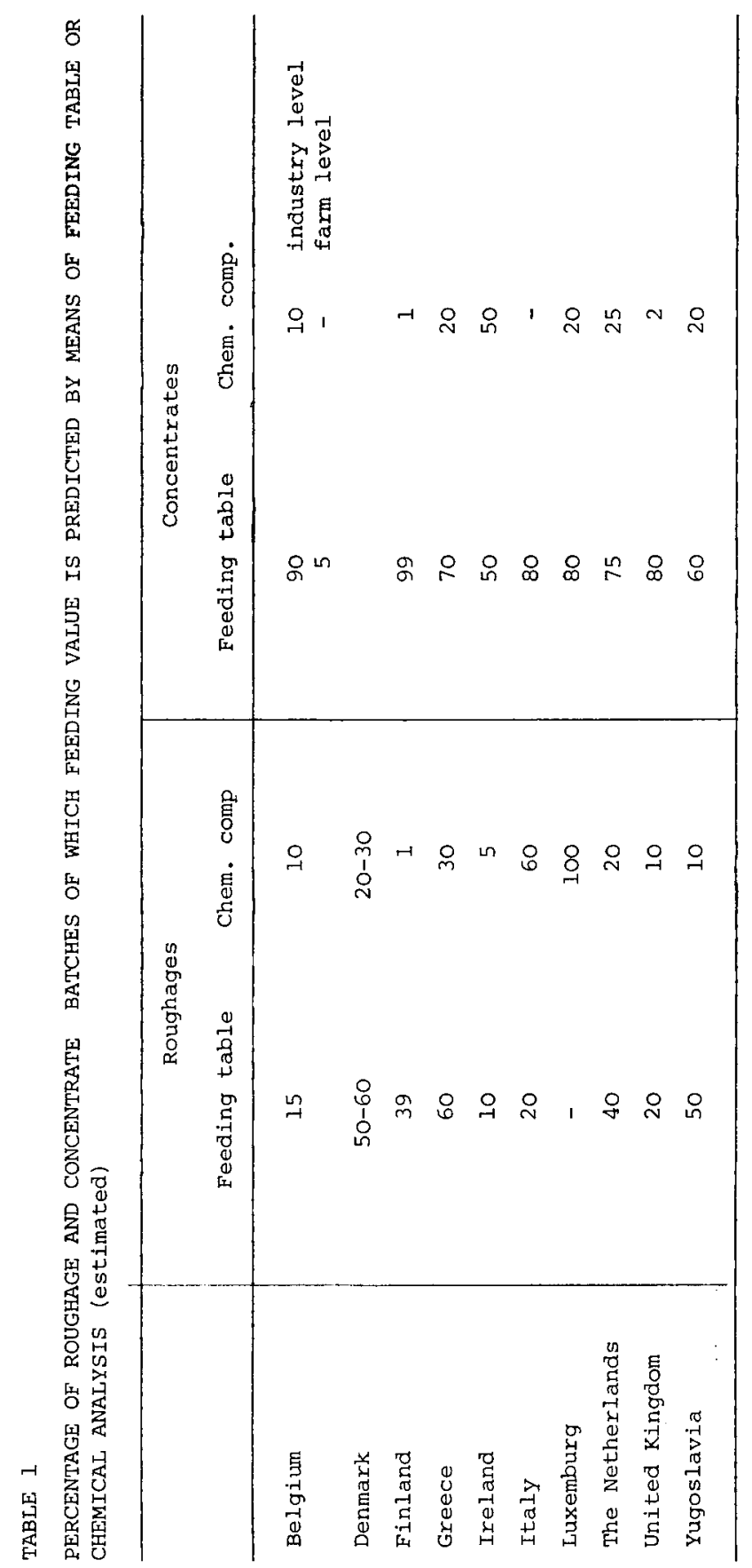


In France, the UK, Ireland, Denmark, the Netherlands, Belgium, Switzerland and Sweden (multiple) regression equations are used for specific roughages (products of grass, legumes, forage maize). The Dutch'Manual for the calculation of the nutritive value of roughages' also provides equations for many other roughages. In most equations crude fibre is the predominant variable in predicting digestibility of organic matter and/or energy value. When MADF is used (UK, Ireland) formulae are also given, based upon this chemical characteristic. In Switzerland evaluation of hay is also done based upon sensorial inspection.

\section{Concentrates}

For concentrates the same questions as for roughages had to be answered. Answering the question, as to what extent feeding tables or chemical analyses are used for the prediction of the feeding value of concentrates, was probably complicated by the fact that for concentrates two categories can be distinguished : concentrate mixtures prepared by the feed industry and those bought or grown at the farm and fed as such or after mixing at the farm. The question was meant for all batches of concentrate ingredients intended to be fed, as such or in a compound feed. Table 1 gives a survey of the answers given. The variability in the answers probably reflects the complexity of the question.

For each country, analyses of dry matter, crude ash, crude protein, crude fat and crude fibre are routine. In France, soluble nitrogen is sometimes given for compound feeds. For the United Kingdom, the in vitro determination of per cent digestible organic matter in dry matter (IVD) is mentioned. The Dutch and the Swiss forms also state incidental analysis of sugars and starch.

For concentrate ingredients the general method for calculating feeding value when chemical composition is known, is to combine chemical composition with fixed digestibilities per feedstuff from a feed table. Only the Dutch feed table gives prescriptions to calculate the feading value of specific feedstuffs (maize, wheat, tapioca and their by-products) directly from chemical composition by means of multiple regression equations. This procedure incorporates the influence of chemical composition upon digestibility, which the former procedure hardly does.

In some countries general formulae are used to predict the feeding value of compound feeds from chemical composition when the ingredients of the feeds are unknown. The following formulae are mentioned:

West Germany: $\mathrm{SE}=0.75 \mathrm{XP}+2 \mathrm{XL}+0.92 \mathrm{XX}$.

$\mathrm{UK}+$ Ireland: $\mathrm{MEF}=0.012 \mathrm{XP}+0.031 \mathrm{XL}+0.005 \mathrm{XF}+0.014 \mathrm{XX}$ (assuming digestibility coefficients of $0.8 ; 0.9 ; 0.4 ; 0.9$ for $\mathrm{XP}, \mathrm{XL}, \mathrm{XF}$ and $\mathrm{XX}$ respectively).

France: UFV $/ 100 \mathrm{~kg} o=0.006 \mathrm{XP}_{0}-0.220 \mathrm{XF}_{0}+0.122 \mathrm{XL}_{0}+124.15$ (equations for the prediction of organic matter digestibility and $\mathrm{ME}$ are also given).

$\mathrm{XP}, \mathrm{XL}, \mathrm{XX}, \mathrm{XF}, o$ stand for crude protein, crude fat, nitrogen free extract, crude fibre and organic matter respectively.

\section{4. - Feedstuff evaluation in research}

A question was put forward to find out to what extent digestibility studies are performed in the respective countries.

Table 2 gives a survey of the activities. 
TABLE 2

PREDICTION OF FEEDING VALUE IN RESEARCH

\begin{tabular}{|c|c|c|c|c|c|}
\hline & \multicolumn{5}{|c|}{ Digestion technique used } \\
\hline & Sheep & Cattle & Tilley/Terry & Cellulase & Nylon bag \\
\hline Belgium & + & + & + & * & + \\
\hline Denmark & + & \pm & + & + & \\
\hline Finland & + & & + & + & \\
\hline France & + & + & & & \\
\hline West Germany & + & + & + & + & \\
\hline Greece & + & & & & \\
\hline Ireland & + & + & + & & \\
\hline Italy & + & + & + & & \\
\hline (Luxemburg) & & & & & \\
\hline The Netherlands & + & + & + & * & \\
\hline Sweden & + & & + & & \\
\hline Switzerland & + & + & + & & \\
\hline United Kingdom & + & + & + & + & + \\
\hline Yugoslavia & + & + & + & & + \\
\hline
\end{tabular}

+ indicating regularly performed; t incidentally; * under study.

In Luxemburg no research is done in this field. In the other countries digestibility trials with sheep are performed. In these trials, the animals in Belgium, Ireland, United Kingdom, Sweden and Switzerland are fed at maintenance, in Italy and Greece somewhat above maintenance. In Denmark and the Netherlands the ration is standardised at $1 \mathrm{~kg}$ dry matter per animal per day. In France the wethers are fed ad libitum. Digestibility trials with cattle are less often performed and the feeding level is variable, at and far above maintenance.

With regard to in vitro procedures : the Tilley/Terry technique, in many countries slightly modified, is mostly used. The cellulase assay is used regularly in Denmark, West Germany, the UK and Finland. Other countries have this technique under study. The nylon bag technique is only used in three countries : Belgium, the UK and Yugoslavia.

\section{5. - Discussion}

For efficient cattle feeding some knowledge of what the animal is consuming has first priority. The beef cattle farmer needs to know the feed intake of the animals. Without knowledge of feed intake, feed evaluation loses much practical sense. Therefore occasional weighings of feed allowance and refusals are very important. 
For the evaluation of the feeding value of the feed consumed knowledge of dry matter content is essential, especially for products like fresh and ensiled roughage. Knowledge of $\mathrm{N}$-content is also desirable to be able to adjust the ration properly when $\mathrm{N}$-content is (relatively) too low. For the calculation of the energy value of a ration or ration components the content of digestible components (whatever the energy evaluation system) has to be known or to be estimated. With knowledge of chemical composition the content of digestible components can be predicted. Normally a closer estimation of content of digestible components is derived by means of an in vitro digestibility determination. In general, each extra step mentioned gives more information, which then means more labour and extra costs. With the increasing size of cattle farms the feed costs, in terms of money involved, are increasingly important. So the larger the farm, the more information is needed concerning the feeding value of the feedstuffs which are to be used. Keeping the above mentioned in mind some remarks can be made as to the results of the questionnaire.

Only a small part of the roughage is actually sampled for chemical analysis : 0 - 25 per cent seems realistic. The method of classifying the roughage on the face of it is employed predominantly. When chemical analyses are practised, it is almost entirely restricted to the Weende procedure which has been improved in the UK by using MADF instead of crude fibre. In most countries the use of regression equations in practice is limited, although in recent year several publications were presented giving relationships between chemical components and digestible components or energy value for several feedstuffs. The use of regression equations is in most cases only valid within a certain climatic zone and for specific feedstuffs, particularly when (crude) fibre is used as a predicting characteristic. This however also holds true for tabulated values.

In vitro digestibility determination procedures give a possibility for a broader application of laboratory evaluation of roughage. The Tilley/Terry technique is often used for research purposes, but in the UK and Ireland only, also for samples from practice. The technical possibility of using an in vitro digestibility procedure $(\mathrm{T}+\mathrm{T}$ or for example cellulase digestibility, both accompanied by analysis of standard samples with known in vivo digestibility), for samples from practice might not yet be fully employed. However, such an analysis unfortunately requires another type of expertise, is time consuming and, therefore, relatively expensive.

Even for concentrate ingredients only a small part is sampled for chemical analysis. For a lot of feedstuffs, at farm level as well as at feed industry level, chemical analysis is restricted to one or two characteristics, for example moisture and crude protein, or crude protein and fat, or starch. In most cases tabulated protein and energy values are used, sometimes after correction for moisture content. However, it is known that variation in chemical composition also influences digestibility for concentrate ingredients, especially for byproducts. Equations are present to calculate feeding values from chemical composition (NEHRING, 1974 , VeEvoEDERTABEL, 1977 ; Report Feedingstuffs Evaluation Unit, Rowett Research Institute). For several concentrate ingredients, relationships between chemical composition and digestibility (feeding value) are not yet available and for these products the use of tabulated digestibilties is the only alternative.

Perhaps in vitro digestibility procedures could be used more often, for concentrates too.

In some countries general equations are used for compound feeds when their ingredients-composition is not known. These equations were derived from 
the results of trials with conventional concentrate mixtures. Two important objections can be made against the use of these general equations :

1. It is possible to compose two compound feeds with the same approximate composition, but with a considerable difference in digestibility. The general equations will give the same feeding value for these two compounds, although the actual feeding value might differ more than 10 per cent. Therefore an additional check with an in vitro digestibility determination (a possibility given in MAFF Bulletin 33) - or, as an educationary method, in vivo studies with a few samples taken at random of concentrate mixtures (West Germany) - seems essential.

2. Although the general equations are meant to be used only for conventionally composed feeds, it cannot be excluded that this procedure is used for ingredient evaluation too. In this case the value of products with a relatively low digestibility will usually be overestimated and those with a higher digestibility will be underestimated. This is certainly undesirable.

Digestibility studies with sheep are the basis for feedstuff evaluation in most countries, although there is a difference in the feeding level used, ranging from " maintenance " till ad libitum. As there is a clear but variable effect of feeding level on the digestibility of diets for sheep (LEAVER et al., 1969; ROBERTSON and VAN SOEST, 1975 ; DIJKSTRA, 1972), a further standardisation is needed to compare digestibility results from different countries or different research institutes. Because maintenance requirement for an adult wether in itself is not well defined, DIJKSTRA (1972) suggested standardising at grams dry matter intake instead of feeding at maintenance requirement for energy. Relating to body weight may lead to misunderstanding because the animal can depose a considerable amount of fat. At our Institute dietary allowance of adult wethers in digestibility studies is normally standardised at $1000 \mathrm{~g}$ dry matter per day. This means $40 \mathrm{~g}$ per $\mathrm{kg}$ metabolic liveweight for animals of $75 \mathrm{~kg}$ liveweight (Texel sheep), taking into consideration that this is an adult liveweight without much body fat deposition. It is suggested to standardise intake at $40 \mathrm{~g}$ dry matter/W/1 information concerning the influence of intake on digestibility is available.

Some further limitations to the ration could also be considered to ensure a normal rumen function : at least 20 per cent long roughage (when the test feed cannot be fed as a sole feed to dairy cattle without rumen disorders), at least 10 per cent crude protein, not more than 10 per cent sugar and not more than 8 per cent crude fat.

\section{References}

DiJksrra N.D., 1972. Invloed van het voedingsniveau op de verteerbaarheid van verschillerde rantsoenen bij herkauwers. VLO 772. Publ. PUDOC Wageningen.

Feedingstuffs Evaluation Unit, 1978. Second Report, 1978. Rowett Research Institute, Aberdeen.

Leaver J.D., Campling C.C., Holmes W., 1969. The effect of level of feeding on the digestibility of diets for sheep and cattle. Anim. Prod. 11, 11.

Nehring K., 1974. Uber den Futterwert verschiedener Getreideprodukte 5. Die Berechnung des Gehaltes an Netto-Energie-Fett (NEF) aus einfachen Kenndaten bei den verschiedenen Getreideprodukten. Arch. Tierern. 24, 5, 429. 
Osbourn D.F., 1978. Principles governing the use of chemical methods of assessing the nutritive value of forages : a review. Anim. Fd. Sci. Tech. 3, 265.

Robertson J.B., Van Soest P.J., 1975. A note on digestibility in sheep as influenced by level of intake. Anim. Prod. $21,89$.

STEg A., Van Der Honing Y., 1979. Relationships between energy values predicted with several feed evaluation systems for dairy cows. Doc. Report no. 49. IVVO, Lelystad.

\section{FEED TABLES}

\section{Belgium, the Netherlands :}

- Veevoedertabel 1973/1977. Publ. CVB. Lelystad.

- Manual for the calculation of the feeding value of roughages 1965/1977. Publ. CVB, Lelystad.

- Voedernormen voor landbouwhuisdieren en voederwaarde der veevoeders. Publ. CVB, Lelystad.

\section{Denmark :}

- Andersen P.E., Just A., 1975. Tabellen over fodermidlers sammensaetning m.m. Publ. Kgl. Danske Landhusholdningsselskab, Copenhagen.

West Germany, Luxemburg, Greece :

- DLG-Futterwerttabelle für Wiederkauer, 1969.

\section{France :}

- Alimentation des Ruminants, 1978. Publ. INRA.

United Kingdom and Ireland :

- MafF, 1975. Energy allowances and feeding systems for ruminants. Tech. Bull. 33.

Italy :

- Borgioli E., 1972. Nutrizione e alimentazione degli animali domestici. Publ. Agricole, Bologna.

- Morrison, Feeds and feeding.

\section{Sweden :}

- Eriksson S., Sanne S., Thomke S., 1972. Fodermedelstabeller och utfodringsrekommendationer. Publ. LT's förlag, Stockholm.

\section{Yugoslavia :}

- Tome, Obradović, Stosić - Norms and tables for feeding animals. 


\section{Appendix}

Investigation on methods of predicting feeding value of feedstuffs for beef cattle

1. Country

Form completed by :

2. Which feed evaluation system is used for beef cattle feedstuffs ? (name)

(address)

2.1 Energy : Name and essential features of system used :

2.2 Protein : Name and essential features of system used :

2.3 Remarks (if thought necessary)

3. Prediction of feeding value of feeds in practice

3.1 Roughages

\subsection{1 from former experience}

3.1.2 by means of feed table name of table

3.1.3 from chemical composition

— which analyses :

- how is feeding value calculated : (if formulae are used, please mention)

3.1.4 otherwise.

\subsection{Concentrates}

\subsection{1 from former experience}

3.2.2. by means of feed table name of table

3.2.3 from chemical composition

- which analyses :

- how is feeding value calculated :

\subsection{4 otherwise.}

4. Prediction of feeding value in research (only applicable if different from 3)

4.1 From digestibility studies with animals :

$$
\text { - sheep }
$$$$
\text { - cattle }
$$

4.2 From digestibility studies in vitro :

- Tillery/Terry technique

- nylon bag technique

- others$$
\text { : yes/no }
$$$$
\text { : yes/no }
$$$$
\text { : yes/no }
$$

feeding level used in these digestibility trials

: yes/no

: yes/no

: yes $/$ no

: yes/no

$:$ yes/no per cent of roughage predicted

: yes/no

: yes/no

: yes/no

$$
\begin{aligned}
& \text { per cent of concentrates predicted } \\
& \text { in this way (estimated) }
\end{aligned}
$$

4.3 otherwise. 